\title{
Recent Progress in Radio-Frequency Sensing Platforms with Graphene/Graphene Oxide for Wireless Health Care System
}

\author{
Hee-Jo Lee
}

Citation: Lee, H.-J. Recent Progress in Radio-Frequency Sensing Platforms with Graphene/Graphene Oxide for Wireless Health Care System. Appl. Sci. 2021, 11, 2291. https://doi.org/10.3390/app11052291

Academic Editor: Hamid Hamedi

Received: 9 February 2021

Accepted: 2 March 2021

Published: 4 March 2021

Publisher's Note: MDPI stays neutral with regard to jurisdictional claims in published maps and institutional affiliations.

Copyright: (C) 2021 by the author. Licensee MDPI, Basel, Switzerland. This article is an open access article distributed under the terms and conditions of the Creative Commons Attribution (CC BY) license (https:// creativecommons.org/licenses/by/ $4.0 /)$.
Department of Physics Education, College of Education, Daegu University, Gyeongbuk 38453, Korea; hjlee@daegu.ac.kr; Tel.: +82-53-850-6972

Featured Application: The author provides recent research and future challenge of RF bio and gas sensing platforms for wireless health care system applications.

\begin{abstract}
In the past decade, graphene has been widely researched to improve or overcome the performance of conventional radio-frequency (RF) nanodevices and circuits. In recent years, novel RF bio and gas sensors based on graphene and its derivatives, graphene oxide (GO) and reduced graphene oxide (rGO), have emerged as new RF sensing platforms using a wireless remote system. Although the sensing schemes are still immature, this review focuses on the recent trends and advances of graphene and GO (rGO)-based RF bio and gas sensors for a real-time and continuous wireless health care system.
\end{abstract}

Keywords: graphene; radio-frequency; sensing platform; wireless health system

\section{Introduction}

Graphene, a single atomic sheet of sp2-bonded carbon (Figure 1a), is a unique and exciting material from many perspectives [1-5]. The thinnest material possesses highly excellent properties, such as mechanical strength, electrical and thermal conductivity, optical transparency, chemical stability, and impermeability. For these reasons, graphene has received significant attention as one of the most interesting materials for a wide variety of potential applications since its discovery in 2004 [6].

In particular, graphene exhibits semi-metallic and electromechanical properties in a wide frequency range, including radio-frequency (RF). Research on graphene-based novel RF devices and circuits has been one of the main topics in the RF nanoelectronics field. For example, graphene with semi-metallic properties was produced by silkscreen printing for a highly conductive radio-frequency identification (RFID) tag antenna [7], similar to the silver antenna but with much higher stability (Figure 1b). Additionally, graphene was studied as a membrane of a frequency mixer, which converts low-frequency into high-frequency, and vice versa, for RF components (Figure 1c) [8]. Furthermore, graphene-based field-effect transistors (G-FETs) were developed with a cutoff frequency of $100 \mathrm{GHz}$ (Figure 1d) [9]. These are proven results as an emblematic protagonist and real solutions for state-of-the-art RF nanoelectronics.

In recent years, promising nanomaterial platforms based on graphene, such as the fundamental two-dimensional (2D) carbon structure with exceptionally high electronic quality and high chemical sensitivity, have emerged for many potential applications, such as bio [10,11], gas [12,13], chemical [14,15], molecular [16,17] and infectious [18,19] sensors. In graphene-based biosensors, the latest example based on nanotechnology in health care is a graphene-based wireless sensor that can make 24-h health care easier to achieve by enabling wireless monitoring of various biomedical events to better assess the health care status of the wearer [20]. Graphene that detects chemical/molecular agents and lengths of exposure can be used as a lightweight and transparent wearable or bio-implantable 
electronic sensor. It can provide an inexpensive sensing scheme to detect in real-time the biomedical substance of interest.

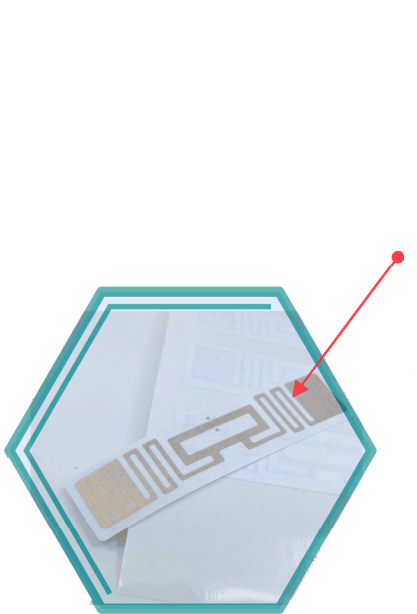

(b)

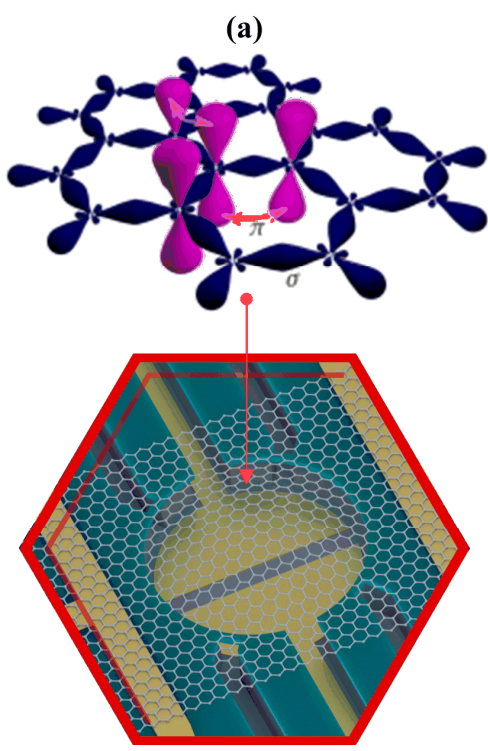

(c)

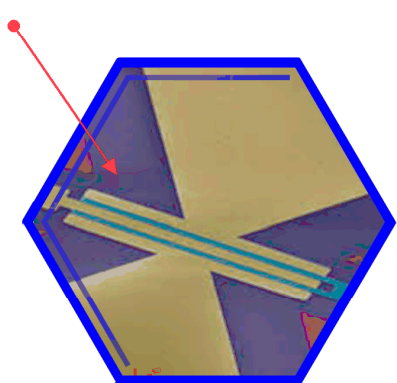

(d)

Figure 1. Graphene-based radio-frequency (RF) nanodevices and circuits. (a) Graphene: a single atomic sheet of sp2-bonded carbon [7]; (b) graphene-based radio-frequency identification (RFID) tag antenna [8]; (c) graphene-based frequency mixer; and (d) graphene-based $100 \mathrm{GHz}$ transistor [9].

Thus, this review focuses on the recent progress in RF bio and gas sensing platforms with graphene/graphene oxide (GO) in a wireless health care system. This paper is organized as follows: first, among the excellent graphene properties, the vital physical and chemical properties of graphene/GO as sensing materials reported in the literature are described, and then the developed graphene/GO-based RF bio and gas sensing platforms are introduced. Next, the pros and cons of these sensing schemes are analyzed, and finally, the challenges and prospects for robust RF sensing platforms in a real-time and continuous health care monitoring system are discussed and suggested. In this paper, the term RF means all science and techniques that are related to transmitting and receiving information or power in the free space (atmosphere) or transmission lines utilizing electromagnetic waves - so-called radio waves and microwaves - and the equipment, e.g., devices and circuits, needed therein for wireless communication.

\section{Graphene and Its Derivatives: Graphene Oxide and Reduced Graphene Oxide}

\subsection{Chemical Structure of Graphene, $G O$, and $r G O$}

In a graphene sheet, three out-shell electrons of a carbon atom occupy three $\mathrm{sp}^{2}$ hybrid orbitals, i.e., $s, p_{x}$, and $p_{y}$, which are shared with the three nearest atoms, forming $\sigma$ bonds $(\sim 0.14 \mathrm{~nm})$. The remaining outer-shell electron occupies a $\mathrm{p}_{\mathrm{z}}$ orbital that is oriented perpendicularly to the plane (Figure 2a) [21,22]. These orbitals hybridize together to form two half-filled bands of free-moving electrons, $\pi$, and $\pi *$, which are responsible for the unique electronic properties in graphene [23].

In the graphene derivatives, $\mathrm{GO}$ and $\mathrm{rGO}$, the obvious difference between these materials is the addition of oxygen atoms bound with the carbon scaffold (Figure $2 b$ ). The GO contains both aromatic $\left(\mathrm{sp}^{2}\right)$ and aliphatic $\left(\mathrm{sp}^{3}\right)$ domains, further expanding the types of interactions that can occur with the surface. Additionally, GO is easily reduced to rGO at high yields (Figure 2c) and can be partly reduced to graphene-like sheets by removing the oxygen-containing moieties with the recovery of a p-conjugated structure [24]. Furthermore, these modified graphene show different chemical and structural properties due to the differences in their chemical compositions (Figure 2b,c). As a result, the most notable differences of GO and rGO are observed in the electrical conductivity, hydrophilic 
behavior, mechanical strength, and dispersibility of these materials. These physical and chemical properties are utilized in energy storage applications $[25,26]$, sensors $[27,28]$, supercapacitors [29,30], solar cells [31,32], and biomedical applications [33,34].
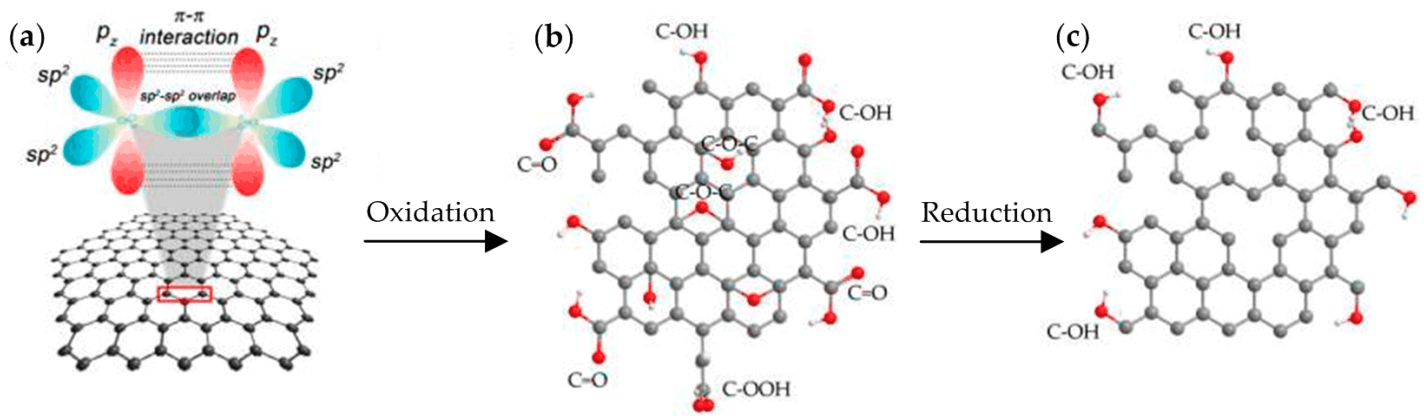

Figure 2. (a) Pristine graphene (pure-arranged carbon atoms) with $\mathrm{sp}^{2}$-hybridized carbon atoms and (b) graphene oxide (GO) and (c) reduced graphene oxide (rGO) of the chemically modified graphene [35].

\subsection{Electronic Properties of Graphene, GO, and $r G O$}

The intrinsic features of graphene serve to strongly support mechanical, thermal, electronic, magnetic, and optical applications. In particular, charge carriers, electrons, in the graphene behave like massless Dirac fermions, which directly affect the linear energy dispersion relation [3]. However, the zero bandgap in graphene makes it unsuitable for FETs (Figure 3a,b). Thus, opening the bandgap in graphene [36] is an urgent issue, and great efforts have been made regarding this topic over the past decade [37-39].

GO is an electronically hybrid-type material containing both conducting $\pi$-states from graphitic $\mathrm{sp}^{2}$ hybridized carbons and a large energy gap between the $\sigma$-states of its $\mathrm{sp}^{3}$ bonded carbons [40]. That is, with a low degree of oxidation, the GO is a semiconducting material, and with a full degree of oxidation, GO is an insulating material [41].

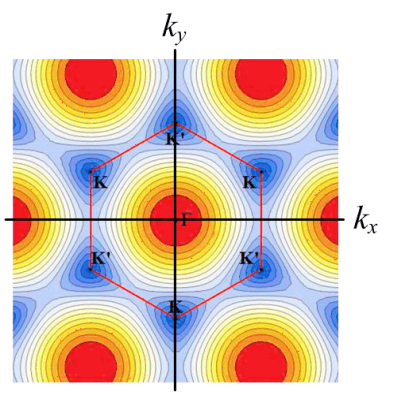

(a)

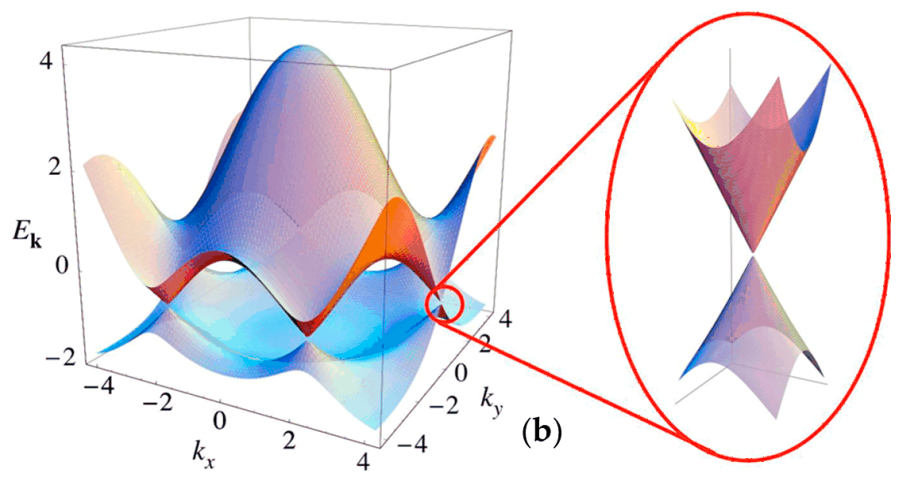

Figure 3. (a) Contour plot of the energy in the first Brillouin zone of graphene [42] and (b) electronic energy dispersion in the honeycomb lattice. Left: energy spectrum for finite values of $t$ and $t^{\prime}$ with $t=2.7 \mathrm{eV}$ and $\mathrm{t}^{\prime}=-0.2 \mathrm{t}$. Right: zoom-in of the energy bands close to one of the Dirac points (reprinted permission from [23]).

\subsection{Optical Properties of Graphene, GO, and $r G O$}

The optical properties of graphene vary with the layer number. It only absorbs $2.3 \%$ of light for single-layer graphene; hence, $97.7 \%$ of light passes through a single-layer with around $0.1 \%$ reflected from its initial trajectory. Figure 4 a represents the optical image of a $50-\mu \mathrm{m}$ aperture partially covered by graphene and its bilayer. The line scan profile shows the intensity of transmitted white light along the yellow line. Inset shows the sample design - a 20- $\mu \mathrm{m}$ thick metal support structure has apertures $20 \mu \mathrm{m}, 30 \mu \mathrm{m}$, and $50 \mu \mathrm{m}$ in diameter with graphene flakes deposited over them. However, with increasing graphene layers that are stacked on top of each other, the greater the light absorption becomes and the 
lower the optical transparency becomes. However, because the relationship between light absorption and the graphene layers is linear, a graphene sample composed of five layers would have absorption of $11.5 \%$ and optical transparency of around 88-88.5\% [43-45] (Figure $4 b$ ).

For GO (rGO), the properties of these materials are dependent upon the thickness of the graphene and the number of graphene layers. Similarly, the optical transmittance of these materials can be tuned by varying the thickness of the material. GO has an optical absorption of $225-275 \mathrm{~nm}$, whereas the absorption in rGO materials is usually around $270 \mathrm{~nm}$. The optical absorption values in these materials are due to the $\pi$ electrons in the graphene sheet and the $\pi-\pi$ transitions. GO can also absorb wavelengths in the ultraviolet (UV) and near-infrared (NIR) regions [46].
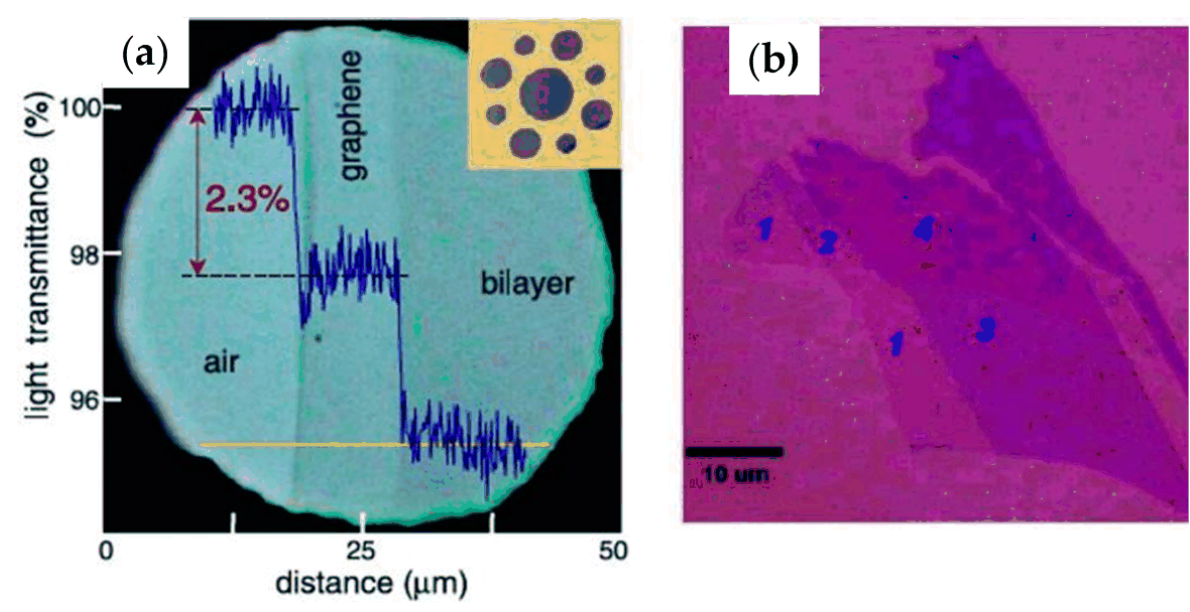

Figure 4. Optical transparency. (a) Light transmittance of monolayer and bilayer graphene and (b) optical image of graphene flakes with one, two, three, and four layers on a 285-nm thick $\mathrm{SiO}_{2}$-on-Si substrate [47].

\section{Graphene/Graphene Oxide-Based Bio and Gas sensors}

\subsection{Performance of Graphene and GO-Based Biosensors}

Table 1 represents the performance of various graphene and its derivatives-based enzymatic biosensors. Here, graphene can detect diverse analytes by enhancing the electron transfer rate [48]. Moreover, rGO and GO play a role in a suitable matrix for immobilization, as shown in Table 1. Here, $\mathrm{rGO}$ was used as a biosensing matrix for detecting important biomarkers, such as $\mathrm{H}_{2} \mathrm{O}_{2}$, glucose, nicotinamide adenine dinucleotide (NADH), DNA, and cholesterol. This is because rGO shows biosensing performance better than GO due to the higher conductivity of rGO [49]. rGO shows less charge transfer resistance than GO due to the conjugated network revival after reduction. In general, graphene derivatives conjugated with nanoparticles indicate the lower limit of detection (LOD) in biosensors.

Table 1. Performance between graphene and graphene derivatives in biosensors.

\begin{tabular}{ccccc}
\hline $\begin{array}{c}\text { Sensing } \\
\text { Materials/Electrodes }\end{array}$ & Analytes & $\begin{array}{c}\text { Detection } \\
\text { Range }\end{array}$ & ${ }^{1}$ LOD & Ref. \\
\hline rGO & $\mathrm{H}_{2} \mathrm{O}_{2}$ & $1.5-28.5 \mu \mathrm{M}$ & $0.5 \mu \mathrm{M}$ & {$[50]$} \\
rGO-PANI-modified $\mathrm{SnO}_{2}$ & Glucose & $0.1 \mathrm{nM}-5 \mathrm{mM}$ & $0.26 \mathrm{nM}$ & {$[51]$} \\
rGO & $2 \mathrm{NADH}$ & $0-500 \mu \mathrm{M}$ & $0.6 \mu \mathrm{M}$ & {$[52]$} \\
rGO-AuNPs & DNA & $0.1 \mathrm{fM}-0.1 \mu \mathrm{M}$ & $35 \mathrm{aM}$ & {$[53]$} \\
GO-Chitosan & DNA & $10 \mathrm{fM}-50 \mathrm{nM}$ & $10 \mathrm{fM}$ & {$[54]$} \\
Graphene-Chitosan & Cholesterol & $0.005-1 \mathrm{mM}$ & $17.39 \mu \mathrm{M}$ & {$[55]$} \\
Graphene-PtNPs & Cholesterol & $0.035-12 \mathrm{mM}$ & $0.2 \mu \mathrm{M}$ & {$[56]$} \\
\hline
\end{tabular}

${ }^{1}$ LOD and ${ }^{2} \mathrm{NADH}$ represent the limit of detection and nicotinamide adenine dinucleotide, respectively. 


\subsection{Performance of Graphene and GO-Based Gas Sensors}

Table 2 shows that the target gases detected by the graphene and its derivatives are $\mathrm{NO}_{2}, \mathrm{NH}_{3}$, and the other organic gases such as ethanol and acetone. Based on the test results, pristine graphene prepared by various grown-methods generally responds well to gases with a concentration below 5\% [57] and shows higher sensitivity and lower LOD than graphene derivatives, as shown in Table 2.

Table 2. Performance between graphene and graphene derivatives in gas sensors.

\begin{tabular}{|c|c|c|c|c|c|}
\hline $\begin{array}{c}\text { Sensing } \\
\text { Materials/Electrodes }\end{array}$ & Target Gas & Sensitivity & LOD & Response Time & Ref. \\
\hline Graphene $\left({ }^{1} \mathrm{MPCVD}\right)$ & $\mathrm{NO}_{2}$ & $1141 \%$ & 785 ppt & $2 \mathrm{~s}$ & [58] \\
\hline Graphene (CVD) & $\mathrm{NH}_{3}$ & $9.3 \times 10^{-5} \mathrm{ppm}^{-1}$ & 17 ppm & $10 \mathrm{~min}$ & [59] \\
\hline $\mathrm{rGO}$ & 2 DMMP & $\Delta \mathrm{R} / \mathrm{R} 0>10 \%$ & 50 ppm & $150 \mathrm{~s}$ & [60] \\
\hline $\mathrm{Pd}^{-}{ }^{3}$ PANI-rGO & $\mathrm{H}_{2}$ & $\Delta \mathrm{R} / \mathrm{R} 0=25 \%$ & $1 \mathrm{vol} \%$ & $20 s$ & [61] \\
\hline AgNPs-rGO & $\mathrm{NH}_{3}$ & $\Delta \mathrm{R} / \mathrm{R}_{0}=6.52 \%$ & $1 \mathrm{ppm}$ & $70 \mathrm{~s}$ & [62] \\
\hline $\mathrm{ZnO}-\mathrm{rGO}$ & Chloroform vapor & $\Delta \mathrm{R} / \mathrm{R}_{0}=1.75 \%$ & 20 ppm & $10 \mathrm{~s}$ & [63] \\
\hline Ni-doped $\mathrm{SnO}_{2} / \mathrm{GO}$ & Acetone & $\Delta \mathrm{G} / \mathrm{G}_{0}=27.5 \%$ & $200 \mathrm{ppm}$ & $5.4 \mathrm{~s}$ & [64] \\
\hline GO-SnO2 & Ethanol & $\mathrm{R}_{\mathrm{a}} / \mathrm{R}_{\mathrm{t}}=160$ & $200 \mathrm{ppm}$ & - & [65] \\
\hline
\end{tabular}

${ }^{1}$ MPCVD, ${ }^{2}$ DMMP, and ${ }^{3}$ PANI represent the microwave plasma chemical vapor deposition, dimethyl methylphosphonate, and polyaniline, respectively.

\section{Graphene/Graphene Oxide-Based RF Biosensing Platforms \\ 4.1. Graphene Oxide-Based Passive RF Biosensors}

Table 3 summarizes the passive RF biosensors combined with GO or rGO for detecting biomolecules, such as glucose, biotin, streptavidin, and DNA, in the past decade. These sensing schemes based on a wafer substrate mainly focused on validation as RF biosensors via diverse RF sensing parameters, e.g., resonant frequency, reflection or transmission coefficient, transmission line (TL) parameters, and impedance.

The tabulated RF biosensors are based on three kinds of passive RF devices and circuits-transmission line [66], capacitor [67], and resonator [68]. First, the rGO-groundsignal-ground (GSG) electrode-based RF sensing scheme was validated with TL parameters, i.e., resistance $(\mathrm{R})$, inductance $(\mathrm{L})$, conductance $(\mathrm{G})$, and capacitance $(\mathrm{C})$, as sensing parameters with different glucose concentrations (Figure 5a) using the measured scatteringparameter (S-parameter). Here, rGO was functionalized with a phenylbutyric acid (PBA) linker to detect glucose molecules (Figure 5b). Park et al. showed that the resistance was the most critical parameter for monitoring the glucose level with stable linearity and small fluctuation.

The other sensing schemes focused on validating RF biosensors through the resonant frequency shift with different analyte concentrations. Furthermore, the coplanar waveguide (CPW)-resonator-based sensing scheme examined the RF characteristics of impedance and permittivity for DNA sensing in the broad frequency region, i.e., $0.5 \mathrm{GHz}$ to $26 \mathrm{GHz}$.

Table 3. GO/rGO-based passive RF biosensors for wireless biosensing platform.

\begin{tabular}{|c|c|c|c|c|c|c|}
\hline $\begin{array}{c}\text { Sensing Materials } \\
\text { (Agents) }\end{array}$ & Analytes & $\begin{array}{l}\text { Operating } \\
\text { Frequency }\end{array}$ & $\begin{array}{c}\text { LOD/ } \\
\text { Sensitivity }\end{array}$ & RF Devices & $\begin{array}{l}\text { System } \\
\text { (Forms) }\end{array}$ & Ref \\
\hline $\begin{array}{c}\text { rGO } \\
\left({ }^{2} \mathrm{PBA}\right)\end{array}$ & Glucose & $0.5-4.5 \mathrm{GHz}$ & $3 \times 10^{-5} \mathrm{~mol} / \mathrm{L}$ & ${ }^{1}$ GSG electrode & $\begin{array}{c}\text { TL } \\
\left({ }^{3} \mathrm{HR}-\mathrm{Si}\right)\end{array}$ & [66] \\
\hline $\begin{array}{c}\mathrm{GO} \\
\text { (Biotin- }{ }^{5} \text { PEG-NH} \\
\text { (B) }\end{array}$ & Streptavidin & $10 \mathrm{GHz}$ & $0.1 \mathrm{mg} / \mathrm{mL}$ & ${ }^{4}$ IDEs & $\begin{array}{l}\text { Resonator } \\
\text { (HR-Si) }\end{array}$ & [67] \\
\hline $\begin{array}{c}\mathrm{GO} \\
\text { (Chitosan) }\end{array}$ & ${ }^{6}$ DNA & $0.5-26 \mathrm{GHz}$ & $1 \mu \mathrm{g} / \mathrm{mL}$ & ${ }^{7} \mathrm{CPW}$-resonator & $\begin{array}{l}\text { Resonator } \\
\text { (Glass) }\end{array}$ & [68] \\
\hline
\end{tabular}

${ }^{1} \mathrm{GSG},{ }^{2} \mathrm{PBA},{ }^{3} \mathrm{HR},{ }^{4} \mathrm{IDEs},{ }^{5} \mathrm{PEG},{ }^{6} \mathrm{DNA}$, and ${ }^{7} \mathrm{CPW}$ represent the ground-signal-ground, pyrene butyric acid, high-resistivity, interdigital capacitor electrodes, polyethylene glycol, deoxyribonucleic acid, and coplanar waveguide, respectively. 


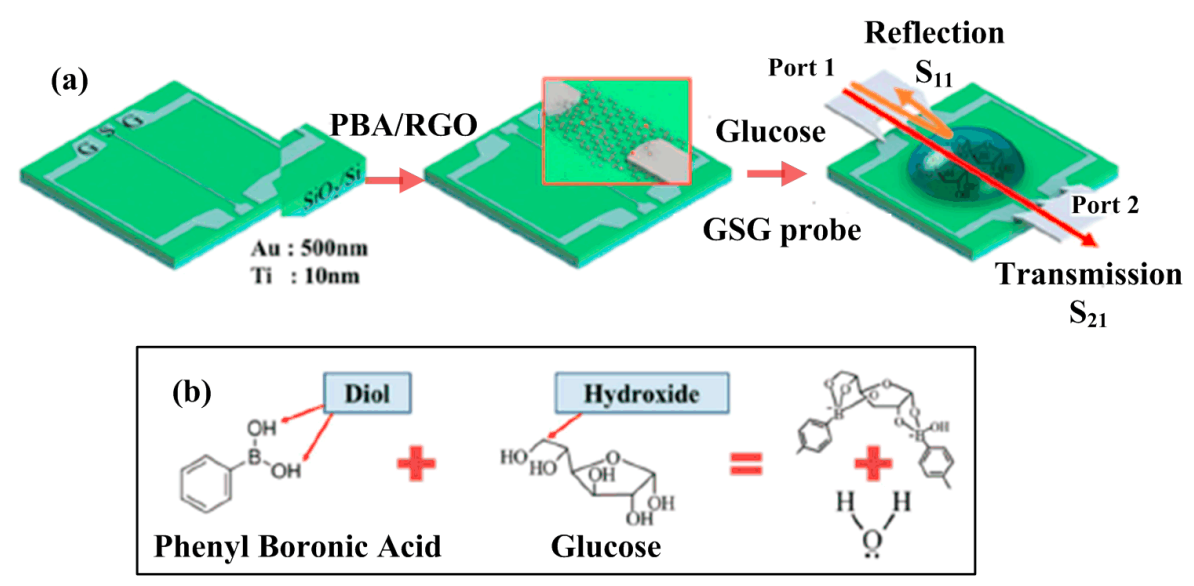

Figure 5. (a) Schematic of rGO-based sensor and measurement parameters of transmission $\left(\mathrm{S}_{21}\right)$ and reflection $\left(\mathrm{S}_{11}\right)$ coefficient in the two-port measurement system and $(\mathbf{b})$ chemical reaction between phenylbutyric acid (PBA) and glucose [66].

\subsection{Graphene-Based Wireless Mobile Health System \\ 4.2.1. Graphene-Based Contact Lens}

In general, wireless systems for sensing platforms combine RF modulation, sensing terminal, and analog memory to record the history of various chemical events, even with a single graphene transistor. This is, however, not possible with conventional solidstate electronic devices. In recent years, the advancement of RF biosensors has proposed a practical wireless sensing platform based on graphene for real-time and continuous monitoring of surface chemical events. This biosensing scheme with a back-gated graphene device showed a distinct conversion of an RF signal when introduced to reduce or oxidize chemical gases or more complex substances, such as protein biomarkers [69].

Figure 6 shows a type of eye-wearable device, smart contact lens, based on an allgraphene harmonic sensor, which could detect biomaterials such as glucose, pathogens, bacteria, and infectious keratitis, for point-of-care (POC) monitoring and real-time wireless biosensing.

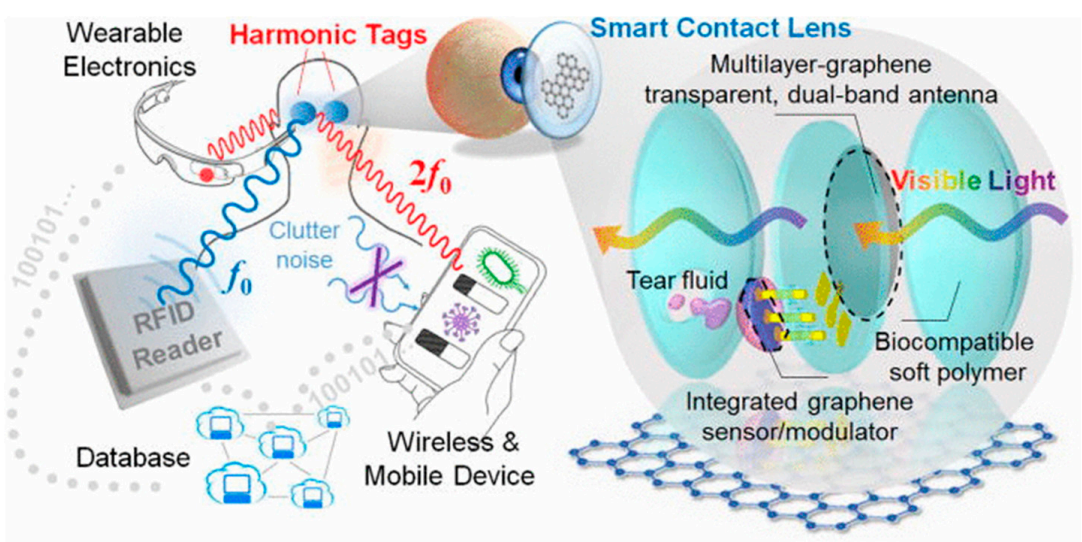

(a)

(b)

Figure 6. A graphene-based harmonic sensor on a soft contact lens. (a) Schematics of a fully passive, transparent, and conformal all-graphene harmonic sensor designed for various point-of-care monitoring and wireless biosensing and (b) an eye-wearable device (smart contact lens) based on the all-graphene harmonic sensor (reprinted with permission from [70]).

In this sensing scheme, Huang et al. [70] presented the concept of a transparent, flexible, and battery-free wireless sensor consisting of a graphene FET-based circuitry and a transparent graphene antenna (Figure 6a). This integrated RF biosensor benefits many wireless sensing and diagnostic applications, particularly for smart contact lenses, glasses, 
and microscope slides that require high sensitivity, high flexibility, and high transparency and must be lightweight (Figure 6b). Moreover, once multiple graphene transistors are used to build a more complicated circuitry, such as a quad-ring topology, the sensor can be activated by wireless power transfer without any need for a battery. Additionally, this biosensing scheme represents numerous possibilities for pervasive health care Internet of Things (IoT) devices and ubiquitous sensor networks [70].

In addition, graphene can protect eyes from electromagnetic (EM) waves that may cause eye diseases such as cataracts [71]. The lens coated with graphene absorbs the EM energy, and the graphene is released in the form of thermal radiation. Consequently, Lee et al. demonstrated that the damage to egg whites could be minimized (Figure 7a,b) [72-74].

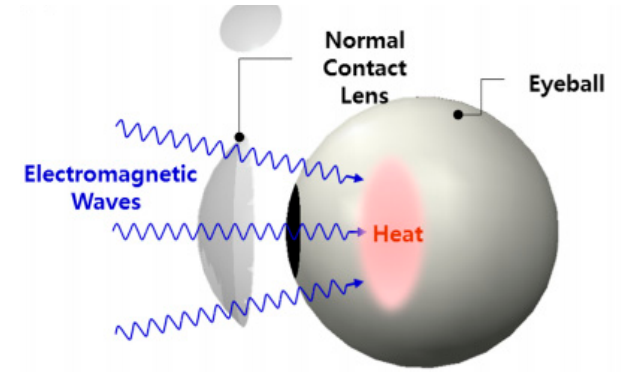

(a)

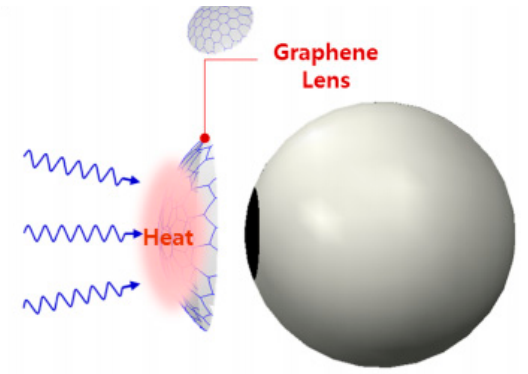

(b)

Figure 7. A smart contact lens with and without graphene coating. (a) Electromagnetic (EM) wave passes through the contact lens and absorbed by an eyeball, possibly causing heat damage inside, and (b) EM energy is absorbed by graphene and dissipated as heat before reaching the interior of the eye (reprinted with permission from [71]).

\subsubsection{Graphene-Based Mental Stress Sensors}

Figure 8 shows an integrated, flexible, and miniaturized wireless mobile health (mHealth) sensing device based on laser-engraved graphene (Figure 8a). This integrated sensor was used for immuno-sensing with proven utility for fast, reliable, sensitive, and non-invasive monitoring of cortisol, a stress hormone, using sweat as a test sample. Based on the test results, Torrente-Rodríguez et al. [75] demonstrated a strong empirical correlation between serum and sweat cortisol, revealing exciting opportunities offered by sweat analysis toward non-invasive dynamic stress monitoring by wearable and portable sensing platforms.
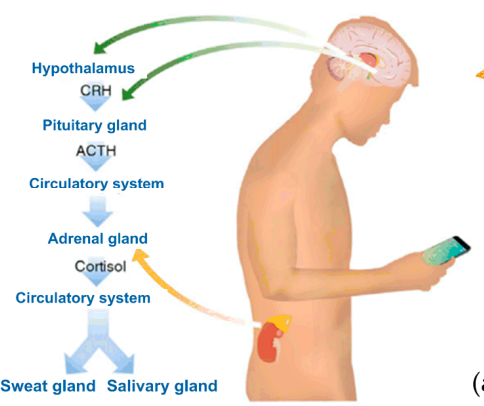

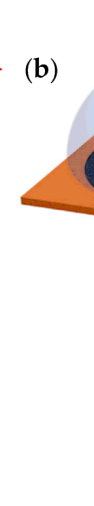

Recongnition

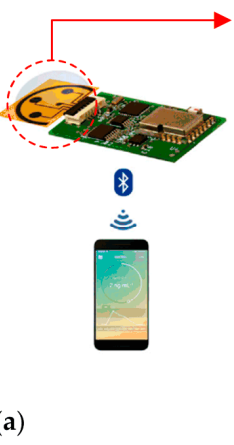

(a)

(c)

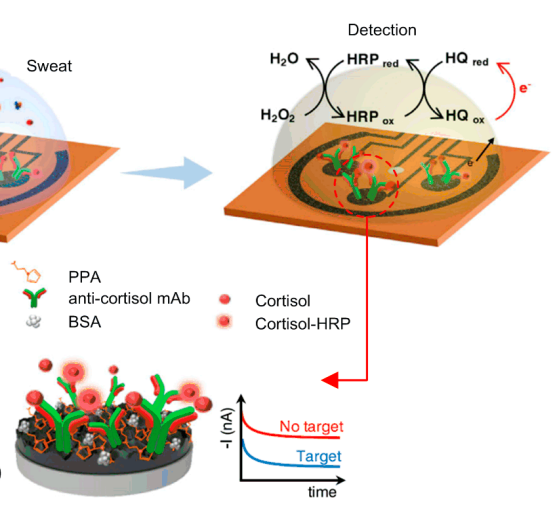

Figure 8. Integrated wireless graphene-based sweat stress sensing platform. (a) Schematic illustration of the origin of cortisol in sweat and saliva and the use of the GS4 to track the circulating cortisol level. CRH, corticotropin-releasing hormone; ACTH, adrenocorticotropic hormone; (b) schematic of the electrochemical detection of cortisol in human sweat; and (c) representation of the affinity-based electrochemical cortisol sensor construction and sensing strategy. HRP, horseradish peroxidase; HQ, hydroquinone; PPA, pyrrole propionic acid; BSA, bovine serum albumin; mAb, monoclonal antibody (reprinted with permission from [75]). 
This patch-type flexible sensor consisted of three working electrodes (WEs) coated with graphene, one $\mathrm{Ag} / \mathrm{AgCl}$ reference electrode (RE), and one counter electrode (CE) coated with graphene (Figure $8 \mathrm{~b}$ ). Cortisol detection through human sweat was achieved by combining carboxylate-rich pyrrole-derivative grafting and subsequent modification on the graphene surface and a competitive sensing strategy. Here, graphene is used as electrodes in terms of the large surface area and fast electron mobility in electrochemical sensing [76], while competitive immuno-sensing strategies offer significant advances in highly selective small hormone molecule detection [77].

\subsubsection{Graphene-Based Pathogenic Bacteria Sensor}

As shown in Figure 9, first, a graphene-based sensing element with a wireless readout coil is generated on silk fibroin (Figure 9a). Next, the ultrathin biosensors are intimately biotransferred from the silk platform onto biomaterials, such as tooth enamel, via dissolution of the supporting silk film (Figure 9b). The extremely large surface area of the graphene and electrodes ensures high adhesive conformability to the rugged surfaces of biomaterials. Because self-assembling designer bifunctional antimicrobial peptide (AMP)-graphene peptides achieve specificity in biological recognition on the graphene (Figure 9c), graphene functionalization can be achieved without degrading its electronic sensing properties.

Furthermore, Figure 9c shows two other significant functionalities of the hybrid-type sensor unit-battery-free operation and wireless remote sensing capability. On recognizing and binding of specific bacterial targets by the immobilized peptides (Figure 9d)), the electrical conductivity (or resistivity) of the graphene film is modulated and wirelessly monitored using an inductively coupled RF reader device. This shows that the critical functionalities of the graphene/silk hybrid sensing elements are derived from a synergistic integration of the individual material properties and components. In the graphene-based biosensor, graphene film was functionalized with a chemically synthesized bifunctional peptide, consisting of a dodecapeptide graphene-binding peptide (GBP), a triglycine linker, and AMP odorranin-hydroxyprogesterone (OHP), which shows activity toward both Gram-negative bacteria (Escherichia coli and Helicobacter pylori) and Gram-positive bacteria (Staphylococcus aureus) [78].

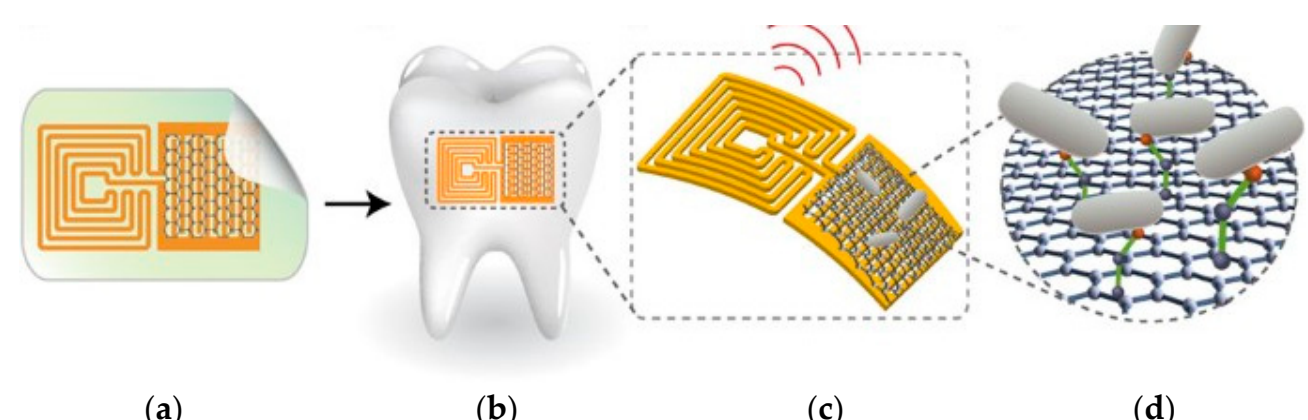

Figure 9. Biotransferrable graphene wireless biosensor. (a) Graphene is printed onto bioresorbable silk, and contacts are formed containing a wireless coil; (b) biotransfer of the nanosensing architecture onto the surface of a tooth; (c) magnified schematic of the sensing element, illustrating wireless readout; and (d) binding of pathogenic bacteria by peptides self-assembled on the graphene nanotransducer (reprinted with permission from [79]).

\section{Graphene/Graphene Oxide-Based RF Gas Sensing Platforms}

\subsection{Graphene Oxide-Based RF Humidity Sensors}

As previously mentioned, because GO is a hydrophilic material, it sensitively responds to the humidity of the environment. Thus, it can be used as a sensing material for a humidity sensor. For example, the electric property of GO material was used by coating a printed graphene antenna with a GO layer in a battery-free wireless RFID humidity sensor, and pristine GO was used, which is a relatively good insulator at room temperature and low 
humidity. On the other hand, the ionic conductivity at high humidity due to the intercalated water increases, and consequently, GO becomes poorly conductive [80].

In the GO-based humidity sensor (Figure 10a), the sensor with a GO layer sensitively responds to the humidity change, whereas the reference sensor without the GO layer does not. The different responses of these two resonators can only be caused by the change in the GO electrical properties due to water uptake [81]. In the resonator with the GO layer, it can be observed that the resonance shifts to a lower frequency and its fractional bandwidth increases as the humidity rises $[82,83]$. This is because both the real $\left(\varepsilon^{\prime}\right)$ and the imaginary $\left(\varepsilon^{\prime \prime}\right)$ parts of the relative permittivity of GO increase as the GO absorbs more water.

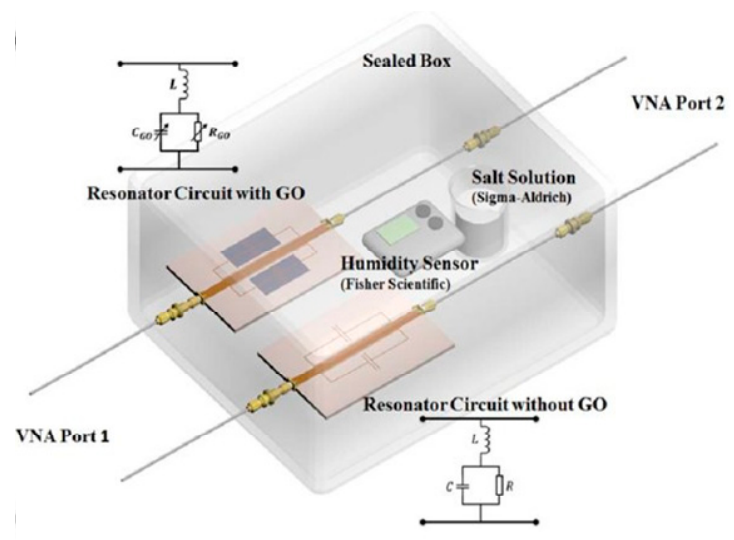

(a)

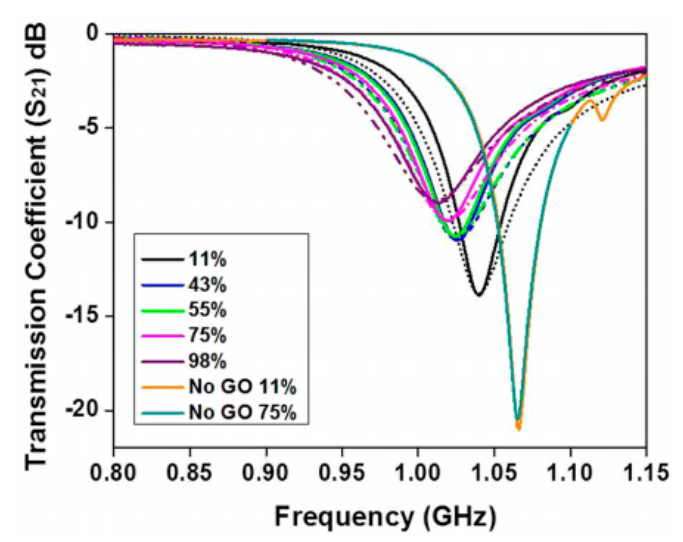

(b)

Figure 10. Graphene oxide-based humidity sensor. (a) Resonator circuits for permittivity measurement of GO and (b) behavior of measured (solid lines) and simulated (dashed lines) $S_{21}$-resonance of the sensors with/without GO layer as RH concentrations increase [84].

Based on the measured results, the resonant frequency and the backscattering phase of the GO/graphene antenna sensitively change with different humidity concentrations (Figure 10b), and the RFID reader can recognize the frequency shift and phase variation. Huang et al. showed the possibility that this sensing scheme can achieve battery-free wireless monitoring of the local humidity with digital identification attached to any location or item.

\subsection{Graphene-Based RFID Gas Sensors}

Figure 11a shows an RFID-based wireless smart-sensor system consisting of a Ptdecorated $\mathrm{rGO}(\mathrm{Pt} / \mathrm{rGO}$ )-based RFID sensor tag and an RFID-reader antenna to detect hydrogen gas. The $\mathrm{Pt} / \mathrm{rGO}$, the sensing material, produced using a simple chemical reduction process, was coated onto an antenna pattern in the sensor tag. The proposed sensor tag exhibited a high sensitivity to hydrogen gas at unprecedentedly low concentrations ( 1 ppm), with wireless communication between the sensor tag and RFID-reader antenna. Lee et al. [85] demonstrated the flexibility and long lifetime of the wireless sensor tag due to the strong immobilization of the $\mathrm{Pt} / \mathrm{rGO}$ on the substrate and battery-independent operation during hydrogen sensing, respectively.

Moreover, the $\mathrm{Pt} / \mathrm{rGO}$-immobilized RFID sensor tag exhibited mechanical stability with bending and twisting deformations due to the flexibility of the plastic sensor substrate and strong adsorption of the $\mathrm{Pt} / \mathrm{rGO}$ on the metal substrate (Figure $11 \mathrm{~b}, \mathrm{c}$ ). 


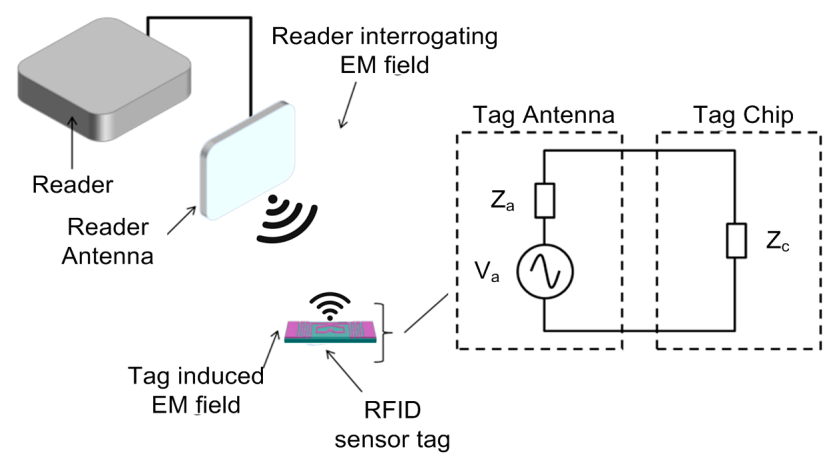

(a)

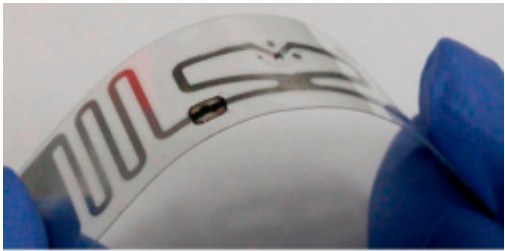

(b)

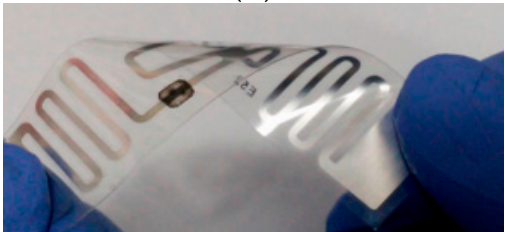

(c)

Figure 11. RFID system for wireless hydrogen sensing platform. (a) Schematic diagram of the ultrahigh-frequency (UHF)RFID sensor tag and antenna and circuit diagram in RFID sensor tag; (b) bending; and (c) twisting of the RFID sensor tag immobilized rGO/Pt (reprinted permission from [85]).

\subsection{Other Graphene/Graphene Oxide-Based RF Gas Sensors}

Other developed graphene and graphene derivative-based RF gas sensors are summarized in Table 4. Based on the tabulated data, the recent research on RF gas sensors with graphene and GO (rGO) has focused on the RFID system for real-time and continuous sensing platforms, such as wireless biosensing platforms. In particular, Na et al. [86], Caccam et al. [87,88], and Le et al. [89] studied gas sensing applications in the UHF band due to its compatibility with the conventional RFID band. The gas sensing schemes based on an antenna [90] and a high-quality (high-Q) resonator [91] were also researched. Additionally, Zhang et al. studied a gas sensing platform that utilizes the non-contact near-field communication (NFC) technique in smartphones [92].

Table 4. Graphene, GO, and rGO-based RF gas sensors for wireless gas sensing platform.

\begin{tabular}{|c|c|c|c|c|c|c|}
\hline Sensing Materials (Forms) & $\begin{array}{c}\text { Target } \\
\text { Gas }\end{array}$ & $\begin{array}{l}\text { Operating } \\
\text { Frequency }\end{array}$ & $\begin{array}{c}\text { LOD/ } \\
\text { Sensitivity }\end{array}$ & $\begin{array}{c}\text { RF Devices/ } \\
\text { Antenna Types }\end{array}$ & $\begin{array}{l}\text { Systems } \\
\text { (Forms) }\end{array}$ & Ref. \\
\hline $\begin{array}{l}\text { Graphene- }^{1} \text { AgNW- }{ }^{2} \text { FET } \\
\text { (Maintained form) }\end{array}$ & ${ }^{3} \mathrm{DMMP}$ & $200 \mathrm{MHz}$ & $5 \mathrm{ppm}$ & Coil antenna & $\begin{array}{l}\text { RFID } \\
\left({ }^{4} \text { PET }\right)\end{array}$ & [86] \\
\hline $\mathrm{rGO} / \mathrm{p}$-doped $\mathrm{Si}$ & ${ }^{5} \mathrm{RH}$ & $865 \mathrm{MHz}$ & $60 \Omega / \mathrm{RH}$ & Meander antenna & $\begin{array}{l}\text { RFID } \\
\text { (Kapton) }\end{array}$ & [87] \\
\hline GO & $\begin{array}{l}\text { Breath } \\
\text { anomalies }\end{array}$ & $915 \mathrm{MHz}$ & $60 \Omega / R H$ & Loop antenna & $\begin{array}{l}\text { RFID } \\
\text { (PET) }\end{array}$ & [88] \\
\hline rGO & $\mathrm{NH}_{3}$ & $915 \mathrm{MHz}$ & $\Delta \mathrm{R} / \mathrm{R}_{0}>6 \%$ & Dipole antenna & $\begin{array}{l}\text { RFID } \\
\text { (Kapton) }\end{array}$ & [89] \\
\hline rGO/Ag-ink-IDEs & $\mathrm{NH}_{3}$ & $5.81 \mathrm{GHz}$ & $50 \mathrm{ppm}$ & IDEs/Patch antenna & $\begin{array}{l}\text { RFID } \\
\left({ }^{6} \text { PCB }\right)\end{array}$ & [90] \\
\hline Graphene (Agglomerated form) & $\mathrm{NH}_{3}$ & $4.20 \mathrm{GHz}$ & - & $\begin{array}{c}{ }^{7} \text { SIW cavity resonator, } \\
{ }^{8} \text { RSR, }{ }^{9} \text { CSRR }\end{array}$ & PCB & [91] \\
\hline rGO-Ag & $\mathrm{NH}_{3}$ & $14 \mathrm{MHz}$ & $5 \mathrm{ppm} / \Delta \mathrm{R} / \mathrm{R}_{0}=1.25 \%$ & Coil antenna & $\begin{array}{c}{ }^{10} \mathrm{NFC} \\
(\mathrm{PET})\end{array}$ & [92] \\
\hline
\end{tabular}

${ }^{1} \mathrm{AgNW},{ }^{2} \mathrm{FET},{ }^{3} \mathrm{DMMP},{ }^{4} \mathrm{PET},{ }^{5} \mathrm{RH},{ }^{6} \mathrm{PCB},{ }^{7} \mathrm{SIW},{ }^{8} \mathrm{RSR},{ }^{9} \mathrm{CSRR}$, and ${ }^{10} \mathrm{NFC}$ represent the silver nanowire, field-effect transistor, dimethyl methylphosphonate, polyethylene terephthalate, relative humidity, printed circuit board, substrate-integrated waveguide, ring slot resonator, complementary split-ring resonator, and near-field communication, respectively.

\section{Discussion and Conclusions}

This paper reviewed the developed RF sensors based on graphene and graphene derivatives (GO and $\mathrm{rGO}$ ) for wireless bio and gas sensing platforms in recent years. Based on research trends, the graphene/GO (rGO)-based RF bio and gas sensors commonly have been approached in terms of RF passive devices and RF systems, i.e., RFID or NFC. In this section, we discuss the pros and cons of the developed RF sensors and suggest a robust RF sensing system for a wireless health care system in the future. 


\subsection{Graphene/GO (rGO)-Based RF Biosensors}

In passive-type RF biosensors (Figure 5 and Table 3), the possibility of RF biosensors based on $\mathrm{GO}$ (rGO) sensing materials using passive RF devices and circuits, e.g., resonator and TL, was demonstrated. They examined the sensing behavior of diverse RF electric parameters, such as resonant frequency, reflection or transmission coefficient, permittivity, resistance, inductance, conductance, and capacitance. However, these studies focused on pilot studies for RF sensing with different analytes and concentrations. Thus, there are many parameters to systematically validate sensing performance, such as the sensitivity, selectivity, and repeatability of proposed RF biosensors with excellent merits, in other words, the direct and straightforward detection of an analyte.

In recent years, novel graphene-based RF biosensors have been proposed for wireless biosensing platforms. First, graphene-based contact lenses (Figure 6) showed the new paradigm for a real-time and continuous wireless sensing platform. This sensor focused on detecting biomolecules, glucose, and cortisol, through tear fluid. Moreover, the sensing information continuously transfers into an RFID reader and then records real-time data. However, there is a risk of heating the human eye due to the sustainable illumination of the radio-wave. For this reason, it was demonstrated that graphene could absorb the radio wave and then dissipate the heat (Figure 7). This is very vital research for wearable and wireless sensing platforms in and on the human body.

Next, the graphene-based stress sensor (Figure 8) is a good candidate for a wireless biosensing platform. The chip-level sensor could detect cortisol, a stress biomarker, using sweat and the working electrodes coated with graphene. This sensor can be readily compatible with a smartphone system and also be suitable for POC diagnostics. Finally, the graphene-based wireless bacteria sensor (Figure 9) is another good candidate for a real-time and continuous pathogenic bacterium sensing platform. First, this sensor has great merit in detecting the single pathogenic bacterium, E. coli, but needs complex functionalization for specific bacterium detection.

\subsection{Graphene/GO (rGO)-Based RF Humidity and Gas Sensors}

In the recent research of RF humidity and gas sensors based on graphene and GO (rGO), two categories of passive RF devices and RF systems for wireless sensing platforms, e.g., mobile health RFID systems, such as wireless biosensing platforms, have been approached.

First, the proposed GO-based humidity sensor (Figure 10) showed the linear relationship between the transmission coefficient $\left(S_{21}\right)$ and relative humidity $(\mathrm{RH})$ concentration. With increasing humidity concentration, this sensor with and without GO was tested in the $\mathrm{RH}$ range from $11 \%$ to $\mathrm{RH} 98 \%$. This resonator-based sensing scheme can be readily recognized with RF signal, but this sensing scheme based on GO may be challenging to determine the exact RH level if the reproducibility of GO is not secured on the resonator. The graphene or GO-based humidity sensing scheme has merits in easy test and fabrication as a sensing platform compared to the bio and gas sensing platform. Next, the developed $\mathrm{Pt} / \mathrm{rGO}$-immobilized RFID sensor (Figure 11) is a good case for wireless gas sensing platform. The bending effect of the sensor was tested. They demonstrated that the distortion did not have a critical effect on the figure of merit of the RFID antenna. The independent performance of the bending effect can be a tremendous advantage for versatile purposes and uses in severe environments.

In conclusion, based on the recent research trends of the RF bio and gas sensing platforms, many researchers continuously focus on developing robust wireless sensing platforms for real-time and continuous health care monitoring. Moreover, to realize the robust RF sensing platforms, researchers should validate prerequisites of sensors such as sensitivity, selectivity, and reproducibility under enough test duration and severe environment and secure the signal-to-noise (SNR) ratio to determine the limit of detection as the RF bio and gas sensors. 
Funding: This research received no external funding.

Institutional Review Board Statement: Not applicable.

Informed Consent Statement: Not applicable.

Data Availability Statement: Data available in a publicly accessible repository.

Conflicts of Interest: The authors declare no conflict of interest.

\section{References}

1. Berger, C.; Song, Z.; Li, T.; Li, X.; Ogbazghi, A.Y.; Feng, R.; Dai, Z.; Marchenkov, A.N.; Conrad, E.H.; First, P.N.; et al. Ultrathin epitaxial graphite: 2D electron gas properties and a route toward graphene-based nanoelectronics. J. Phys. Chem. B 2004, 108, 19912-19916. [CrossRef]

2. Novoselov, K.S.; Geim, A.K.; Morozov, S.V.; Jiang, D.; Zhang, Y.; Dubonos, S.V.; Grigorieva, I.V.; Firsov, A.A. Electric field effect in atomically thin carbon films. Science 2004, 306, 666-669. [CrossRef]

3. Novoselov, K.S.; Geim, A.K.; Morozov, S.V.; Jiang, D.; Katsnelson, M.I.; Grigorieva, I.V.; Dubonos, S.V.; Firsov, A.A. Twodimensional gas of massless Dirac fermions in graphene. Nature 2005, 438, 197-200. [CrossRef] [PubMed]

4. Zhang, Y.B.; Tan, Y.-W.; Stormer, H.L.; Kim, P. Experimental observation of the quantum Hall effect and Berry's phase in graphene. Nature 2005, 438, 201-204. [CrossRef]

5. Bunch, J.S.; Yaish, Y.; Brink, M.; Bolotin, K.; McEuen, P.L. Coulomb oscillations and Hall effect in quasi-2D graphite quantum dots. Nano Lett. 2005, 5, 287-290. [CrossRef]

6. Liao, L.; Duan, X.F. Graphene for radio frequency electronics. Mater. Today 2012, 15, 328-338. [CrossRef]

7. Graphene RFID Inlay. Available online: https:/ / www.yourfid.top/product/graphene-rfid-inlay/ (accessed on 24 January 2021).

8. Alba, R.D.; Massel, F.; Storch, I.R.; Abhilash, T.S.; Hui, A.; McEuen, P.L.; Craighead, H.G.; Parpia, J.M. Tunable phonon-cavity coupling in graphene membrane. Nat. Nanotechnol. 2016, 11, 741-746. [CrossRef] [PubMed]

9. Lin, Y.-M.; Dimitrakopoulos, C.; Jenkins, K.A.; Farmer, D.B.; Chiu, H.-Y.; Grill, A.; Avouris, P. 100-GHz transistors from wafer-scale epitaxial graphene. Science 2010, 327, 662. [CrossRef] [PubMed]

10. Bolotsky, A.; Butler, D.; Dong, C.; Gerace, K.; Glavin, N.R.; Muratore, C.; Robinson, J.A.; Ebrahimi, A. Two-dimensional materials in biosensing and healthcare: From in vitro diagnostics to optogenetics and beyond. ACS Nano 2019, 13, 9781-9810. [CrossRef] [PubMed]

11. Thangamuthu, M.; Hsieh, K.Y.; Kumar, P.V.; Chen, G.-Y. Graphene- and graphene oxide-based nanocomposite platforms for electrochemical biosensing applications. Int. J. Mol. Sci. 2016, 20, 2975. [CrossRef] [PubMed]

12. Buckley, D.; Black, N.C.G.; Castanon, E.G.; Melios, C.; Hardman, M.; Kazakova, O. Frontiers of graphene and 2D material-based gas sensors for environmental monitoring. 2D Mater. 2020, 7, 1-48. [CrossRef]

13. Choi, J.H.; Lee, J.; Byeon, M.; Hong, T.E.; Park, H.; Lee, C.Y. Graphene-based gas sensor with high sensitivity and minimal sensor-to-sensor variation. ACS Appl. Nano Mater. 2020, 3, 2257-2265. [CrossRef]

14. Singh, E.; Meyyappan, M.; Nalwa, H.S. Flexible graphene-based wearable gas and chemical sensors. ACS Appl. Mater. Interfaces 2017, 9, 34544-34586. [CrossRef]

15. Fowler, J.D.; Allen, M.J.; Tung, V.C.; Yang, Y.; Kaner, R.B.; Weiller, B.H. Practical chemical sensors from chemically derived graphene. ACS Nano 2009, 3, 301-306. [CrossRef] [PubMed]

16. Lv, R.; Li, Q.; Botello-Méndez, A.R.; Hayashi, T.; Wang, B.; Berkdemir, A.; Hao, Q.; Elías, A.L.; Cruz-Silva, R.; Gutiérrez, H.R.; et al. Nitrogen-doped graphene: Beyond single substitution and enhancing molecular sensing. Sci. Rep. 2012, 2, 586. [CrossRef]

17. Lv, R.; Santos, M.C.D.; Antonelli, C.; Feng, S.; Fujisawa, K.; Berkdemir, A.; Cruz-Silva, R.; Elías, A.L.; Perea-Lopez, N.; López-Urías, F.; et al. Large-area Si-doped graphene: Controllable synthesis and enhanced molecular sensing. Adv. Mater. 2014, 26, 1-7. [CrossRef] [PubMed]

18. Vermisoglou, E.; Panáček, D.; Jayaramulu, K.; Pykal, M.; Frébort, I.; Kolář, M.; Hajdúch, H.; Zbořil, R.; Otyepka, M. Human virus detection with graphene-based materials. Biosens. Bioelectron. 2020, 166, 1-21. [CrossRef] [PubMed]

19. Jiang, Z.; Feng, B.; Xu, J.; Qing, T.; Zhang, P.; Qing, Z. Graphene biosensors for bacterial and viral pathogens. Biosens. Bioelectron. 2020, 166, 1-19. [CrossRef] [PubMed]

20. Wang, L.; Lou, Z.; Jiang, K.; Shen, G. Bio-multifunctional smart wearable sensors for medical devices. Adv. Intell. Syst. 2019, 1, 1900040-1-1900040-22. [CrossRef]

21. Yang, G.; Li, L.; Lee, W.B.; Ng, M.C. Structure of graphene and its disorders: A review. Sci. Technol. Adv. Mater. 2018, 19, 613-648. [CrossRef] [PubMed]

22. Cooper, D.R.; D'Anjou, B.; Ghattamaneni, N.; Harack, B.; Hilke, M.; Horth, A.; Majlis, N.; Massicotte, M.; Vandsburger, L.; Whiteway, E.; et al. Experimental review of graphene. ISRN Condens. Matter. Phys. 2012, 2012, 1-56. [CrossRef]

23. Castro Neto, A.H.; Guinea, F.; Peres, N.M.R.; Novoselov, K.S.; Geim, A.K. The electronic properties of graphene. Rev. Mod. Phys. 2009, 81, 109-162. [CrossRef]

24. Sharma, N.; Sharma, V.; Jain, Y.; Kumari, M.; Gupta, R.; Sharma, S.K.; Sachdev, K. Synthesis and characterization of graphene oxide (GO) and reduced graphene oxide (rGO) for gas sensing application. Macromol. Symp. 2017, 376, 1700006-1-1700006-5. [CrossRef] 
25. Xu, J.; Wang, K.; Zu, S.-Z.; Han, B.-H.; Wei, Z. Hierarchical nanocomposites of polyaniline nanowire arrays on graphene oxide sheets with synergistic effect for energy storage. ACS Nano 2010, 4, 5019-5026. [CrossRef] [PubMed]

26. Bo, Z.; Shuai, X.; Mao, S.; Yang, H.; Qian, J.; Chen, J.; Yan, J.; Cen, K. Green preparation of reduced graphene oxide for sensing and energy storage applications. Sci. Rep. 2014, 4, 4684. [CrossRef]

27. Robinson, J.T.; Perkins, F.K.; Snow, E.S.; Wei, Z.; Sheehan, P.E. Reduced graphene oxide molecular sensors. Nano Lett. 2008, 8, 3137-3140. [CrossRef]

28. Borini, S.; White, R.; Wei, D.; Astley, M.; Haque, S.; Spigone, E.; Harris, N.; Kivioja, J.; Ryhänen, T. Ultrafast graphene oxide humidity sensors. ACS Nano 2013, 7, 11166-11173. [CrossRef]

29. Down, M.P.; Rowley-Neale, S.J.; Smith, G.C.; Banks, C.E. Fabrication of graphene oxide supercapacitor devices. ACS Appl. Energy Mater. 2018, 1, 707-714. [CrossRef]

30. Li, Z.; Gadipelli, S.; Yang, Y.; He, G.; Guo, J.; Li, J.; Lu, Y.; Howard, C.A.; Brett, D.J.L.; Parkin, I.P.; et al. Exceptional supercapacitor performance from optimized oxidation of graphene-oxide. Energy Storage Mater. 2019, 17, 12-21. [CrossRef]

31. Li, S.-S.; Tu, K.-H.; Lin, C.-C.; Chen, C.-W.; Chhowalla, M. Solution-processable graphene oxide as an efficient hole transport layer in polymer solar cells. ACS Nano 2010, 4, 3169-3174. [CrossRef] [PubMed]

32. Wu, Z.; Bai, S.; Xiang, J.; Yuan, Z.; Yang, Y.; Cui, W.; Gao, X.; Liu, Z.; Jin, Y.; Sun, B. Efficient planar heterojunction perovskite solar cell employing graphene oxide as hole conductor. Nanoscale 2014, 6, 10505-10510. [CrossRef] [PubMed]

33. Chung, C.; Kim, Y.-K.; Shin, D.; Ryoo, S.-R.; Hong, B.H.; Min, D.-H. Biomedical applications of graphene and graphene oxide. Acc. Chem. Res. 2013, 46, 2211-2224. [CrossRef]

34. Georgakilas, V.; Tiwari, J.N.; Kemp, K.C.; Perman, J.A.; Bourlinos, A.B.; Kim, K.S.; Zboril, R. Noncovalent functionalization of graphene and graphene oxide for energy materials, biosensing, catalytic, and biomedical applications. Chem. Rev. 2016, 116, 5464-5519. [CrossRef]

35. Lee, H.-J.; Yook, J.-G. Graphene nanomaterials-based radio-frequency/microwave biosensors for biomaterials detection. Materials 2019, 12, 952. [CrossRef] [PubMed]

36. Geim, A.K.; Novoselov, K.S. The rise of graphene. Nat. Mater. 2007, 6, 183-191. [CrossRef]

37. Sarkar, S.; Bekyarova, E.; Niyogi, S.; Haddon, R.C. Diels-Alder chemistry of graphite and graphene: Graphene as diene and dienophile. J. Am. Chem. Soc. 2011, 133, 3324-3327. [CrossRef]

38. Xu, X.; Liu, C.; Sun, Z.; Cao, T.; Zhang, Z.; Wang, E.; Liu, Z.; Liu, K. Interfacial engineering in graphene band-gap. Chem. Soc. Rev. 2018, 9, 1-65.

39. Allen, M.J.; Tung, V.C.; Kaner, R.B. Honeycomb carbon: A review of graphene. Chem. Rev. 2010, 110, 132-145. [CrossRef]

40. Lu, G.; Yu, K.; Wen, Z.; Chen, J. Semiconducting graphene: Converting graphene from semimetal to semiconductor. Nanoscale 2013, 5, 1353-1358. [CrossRef] [PubMed]

41. Gomez, C.V.; Robalino, E.; Haro, D.; Tene, T.; Escudero, P.; Haro, A.; Orbe, J. Structural and electronic properties of graphene oxide for different degree of oxidation. Mater. Today Proc. 2016, 3, 796-802.

42. Optical Properties of Graphene. Available online: http:// demonstrations.wolfram.com/OpticalPropertiesOfGraphene/ (accessed on 27 January 2021).

43. Wang, X.; Nan, H.; Dai, W.; Lin, Q.; Liu, Z.; Gu, X.; Ni, Z.; Xiao, S. Optical studies of the thermal stability of InSe nanosheets. Appl. Surf. Sci. 2019, 467-468, 860-867. [CrossRef]

44. Bonaccorso, F.; Sun, Z.; Hasan, T.A.; Ferrari, A.C. Graphene photonics and optoelectronics. Nat. Photon. 2010, 4, 611-622. [CrossRef]

45. What Are the Optical Properties of Graphene? Available online: https://www.azooptics.com/Article.aspx?ArticleID=1537 (accessed on 24 January 2021).

46. How Is Graphene Oxide Used in Optical Applications? Available online: https://www.azooptics.com/Article.aspx?ArticleID=17 57 (accessed on 24 January 2021).

47. Zhu, Y.; Murali, S.; Cai, W.; Li, X.; Suk, J.W.; Potts, J.R.; Ruoff, R.S. Graphene and graphene oxide: Synthesis, properties, and applications. Adv. Mater. 2010, 4, 1-19.

48. Lin, W.J.; Liao, C.S.; Jhang, J.H.; Tsai, Y.C. Graphene modified basal and edge plane pyrolytic graphite electrodes for electrocatalytic oxidation of hydrogen peroxide and $\beta$-nicotinamide adenine dinucleotide. Electrochem. Commun. 2009, 11, 2153-2156. [CrossRef]

49. Casero, E.; Parra-Alfambra, A.; Petit-Domínguez, M.; Pariente, F.; Lorenzo, E.; Alonso, C. Differentiation between graphene oxide and reduced graphene by electrochemical impedance spectroscopy (EIS). Electrochem. Commun. 2012, 20, 63-66. [CrossRef]

50. Zou, N.; Wei, X.; Zong, Z.; Li, X.; Wang, Z.; Wang, X. A novel enzymatic biosensor for detection of intracellular hydrogen peroxide based on 1-aminopyrene and reduced graphene oxides. J. Chem. Sci. 2019, 131, 28. [CrossRef]

51. Wu, S.; Su, F.; Dong, X.; Ma, C.; Pang, L.; Peng, D.; Wang, M.; He, L.; Zhang, Z. Development of glucose biosensors based on plasma polymerization-assisted nanocomposites of polyaniline, tin oxide, and three-dimensional reduced graphene oxide. Appl. Surf. Sci. 2017, 401, 262-270. [CrossRef]

52. Tabrizi, M.A.; Zand, Z. A Facile One-Step Method for the Synthesis of Reduced Graphene Oxide Nanocomposites by NADH as Reducing Agent and Its Application in NADH Sensing. Electroanalysis 2014, 26, 171-177. [CrossRef]

53. Wang, J.; Shi, A.; Fang, X.; Han, X.; Zhang, Y. An ultrasensitive supersandwich electrochemical DNA biosensor based on gold nanoparticles decorated reduced graphene oxide. Anal. Biochem. 2015, 469, 71-75. [CrossRef] 
54. Singh, A.; Sinsinbar, G.; Choudhary, M.; Kumar, V.; Pasricha, R.; Verma, H.; Singh, S.P.; Arora, K. Graphene oxide-chitosan nanocomposite based electrochemical DNA biosensor for detection of typhoid. Sens. Actuators Chem. 2013, 185, 675-684. [CrossRef]

55. Li, Z.; Xie, C.; Wang, J.; Meng, A.; Zhang, F. Direct electrochemistry of cholesterol oxidase immobilized on chitosan-graphene and cholesterol sensing. Sens. Actuators Chem. 2015, 208, 505-511. [CrossRef]

56. Dey, R.S.; Raj, C.R. Development of an amperometric cholesterol biosensor based on graphene- Pt nanoparticle hybrid material. J. Phys. Chem. C 2010, 114, 21427-21433. [CrossRef]

57. Tian, W.; Liu, X.; Yu, W. Research progress of gas sensor based on graphene and its derivatives: A review. Appl. Sci. 2018, 8, 1118. [CrossRef]

58. Wu, J.; Feng, S. Facile Synthesis of 3D Graphene Flowers for Ultrasensitive and Highly Reversible Gas Sensing. Adv. Funct. Mater. 2016, 26, 7462-7469. [CrossRef]

59. Ricciardella, F.; Vollebregt, S. High sensitive gas sensors realized by a transfer-free process of CVD graphene. In Proceedings of the 2016 IEEE Sensors, Orlando, FL, USA, 30 October-3 November 2016.

60. Wang, Y.; Peng, C. Vertical Response Gas Sensor Based on Three-Dimensional Porous Graphene Ultrathin Film and Its Preparation Method. Patent CN106596654A, 16 April 2017.

61. Zou, Y.; Wang, Q. Doping composite of polyaniline and reduced graphene oxide with palladium nanoparticles for roomtemperature hydrogen-gas sensing. Int. J. Hydrog. Energy 2016, 41, 5396-5404. [CrossRef]

62. Karaduman, I.; Er, E. Room-temperature ammonia gas sensor based on reduced graphene oxide nanocomposites decorated by $\mathrm{Ag}$, Au and Pt nanoparticles. J. Alloys Compd. 2017, 722, 569-578. [CrossRef]

63. Zhou, Y.; Lin, X. Study on gas sensing of reduced graphene oxide/ZnO thin film at room temperature. Sens. Actuators B Chem. 2017, 240, 870-880. [CrossRef]

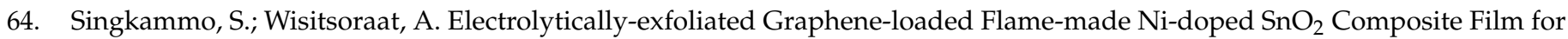
Acetone Sensing. ACS Appl. Mater. Interfaces 2015, 7, 3077-3092. [CrossRef]

65. Han, M.; Liu, W. Graphene oxide- $\mathrm{SnO}_{2}$, nanocomposite: Synthesis, characterization, and enhanced gas sensing properties. J. Mater. Sci. Mater. Electron. 2017, 28, 16973-16980. [CrossRef]

66. Park, B.; Park, H.G.; Ji, J.-H.; Cho, J.; Jun, S.C. A reduced graphene oxide based radio frequency glucose sensing device using multi-dimensional parameters. Micromachines 2016, 7, 136. [CrossRef]

67. Yoon, H.S.; Lim, J.W.; Son, S.U.; Kim, D.-H.; Song, I.S.; Jun, S.C. Biotin-streptavidin detection with a graphene-oxide supported radio-frequency resonator. Appl. Phys. Lett. 2013, 102, 193701-1-193701-4.

68. Iramnaaz, I.; Xing, Y.; Xue, K.; Zhuang, Y.; Fitch, R. Graphene based RF/microwave impedance sensing of DNA. In Proceedings of the 2011 IEEE 61st Electronic Components and Technology Conference, Lake Buena Vista, FL, USA, 31 May-3 June 2011; IEEE: Piscataway, NJ, USA, 2011.

69. Huang, H.; Tao, L.; Liu, F.; Ji, L.; Hu, Y.; Cheng, M.M.-C.; Chen, P.-Y.; Akinwande, D. Chemical-sensitive graphene modulator with a memory effect for internet-of-things applications. Microsyst. Nanoeng. 2016, 2, 16018-1-16018-9. [CrossRef]

70. Huang, H.; Sakhdari, M.; Hajizadegan, M.; Shahini, A.; Akinwande, D.; Chen, P.-Y. Toward transparent and self-activated graphene harmonic transponder sensors. Appl. Phys. Lett. 2016, 108, 173503-1-173503-5. [CrossRef]

71. Lee, S.; Jo, I.; Kang, S.; Jang, B.; Moon, J.; Park, J.B.; Lee, S.; Rho, S.; Kim, Y.; Hong, B.H. Smart contact lenses with graphene coating for electromagnetic interference shielding and dehydration protection. ACS Nano 2017, 11, 5318-5324. [CrossRef]

72. Kim, Y.-J.; Kim, Y.; Novoselov, K.; Hong, B.H. Engineering electrical properties of graphene: Chemical approaches. 2D Mater. 2015, 2, 042001-1-042001-17. [CrossRef]

73. Kang, J.; Kim, D.; Kim, Y.; Choi, J.-B.; Hong, B.H.; Kim, S.W. High-performance near-field electromagnetic wave attenuation in ultra-thin and transparent graphene films. 2D Mater. 2017, 4, 025003-1-025003-10. [CrossRef]

74. Kang, S.; Choi, H.; Lee, S.B.; Park, S.C.; Park, J.B.; Lee, S.; Kim, Y.; Hong, B.H. Efficient heat generation in large-area graphene films by electromagnetic wave absorption. 2D Mater. 2017, 4, 025037-1-025037-6. [CrossRef]

75. Torrente-Rodríguez, R.M.; Tu, J.; Yang, Y.; Min, J.; Wang, M.; Song, Y.; Yu, Y.; Xu, C.; Ye, C.; IsHak, W.W.; et al. Investigation of cortisol dynamics in human sweat using a graphene-based wireless mhealth system. Cell 2020, 2, 921-937. [CrossRef] [PubMed]

76. Shao, Y.; Wang, J.; Wu, H.; Liu, J.; Aksay, I.A.; Lin, Y. Graphene based electrochemical sensors and biosensors: A review. Electroanalysis 2010, 22, 1027-1036. [CrossRef]

77. Wang, X.; Cohen, L.; Wang, J.; Walt, D.R. Competitive immunoassays for the detection of small molecules using single molecule arrays. J. Am. Chem. Soc. 2018, 140, 18132-18139. [CrossRef]

78. Chen, L.; Li, Y.; Li, J.; Xu, X.; Lai, R.; Zou, Q. An antimicrobial peptide with antimicrobial activity against Helicobacter pylori. Peptides 2007, 28, 1527-1531. [CrossRef] [PubMed]

79. Mannoor, M.S.; Tao, H.; Clayton, J.D.; Sengupta, A.; Kaplan, D.L.; Naik, R.R.; Verma, N.; Omenetto, F.G.; McAlpine, M.C. Graphene-based wireless bacteria detection on tooth enamel. Nat. Commun. 2012, 3, 763. [CrossRef] [PubMed]

80. Yao, Y.; Chen, X.; Zhu, J.; Zeng, B.; Wu, Z.; Li, X. The effect of ambient humidity on the electrical properties of graphene oxide films. Nanoscale Res. Lett. 2012, 7, 1-7. [CrossRef]

81. Bayer, T.; Bishop, S.; Perry, N.; Sasaki, K.; Lyth, S. Tunable mixed ionic/electronic conductivity and permittivity of graphene oxide paper for electrochemical energy conversion. ACS Appl. Mater. Interfaces 2016, 8, 11466-11475. [CrossRef] 
82. Bi, H.; Yin, K.; Xie, X.; Ji, J.; Wan, S.; Sun, L.; Terrones, M.; Dresselhaus, M. Ultrahigh humidity sensitivity of graphene oxide. Sci. Rep. 2013, 3, 2714. [CrossRef] [PubMed]

83. Cheng, B.; Tian, B.; Xie, C.; Xiao, Y.; Lei, S. Highly sensitive humidity sensor based on amorphous $\mathrm{Al}_{2} \mathrm{O}_{3}$ nanotubes. J. Mater. Chem. 2011, 21, 1907-1912. [CrossRef]

84. Huang, X.; Leng, T.; Georgiou, T.; Abraham, J.; Nair, R.R.; Novoselov, K.S.; Hu, Z. Graphene-oxide dielectric permittivity at GHz and its applications for wireless humidity sensing. Sci. Rep. 2018, 8, 43. [CrossRef] [PubMed]

85. Lee, J.S.; Oh, J.K.; Jang, J.S. Wireless hydrogen smart sensor based on Pt/graphene-immobilized radio-frequency identification tag. ACS Nano 2015, 9, 7783-7790. [CrossRef]

86. Na, K.M.; Ma, H.G.; Park, J.H.; Yeo, J.H.; Park, J.-U.; Bien, F. Graphene-based wireless environment gas sensor on PET substrate. IEEE Sens. J. 2016, 16, 5003-5009. [CrossRef]

87. Caccam, M.C.; Mulla, M.Y.S.; Natale, C.D.; Marrocco, G. Wireless monitoring of breath by means of a graphene oxide-based radiofrequency identification wearable sensor. In Proceedings of the 2017 11th European Conference on Antennas and Propagation, Paris, France, 19-24 March 2017; IEEE: Piscataway, NJ, USA, 2017.

88. Caccam, M.C.; Mulla, M.Y.S.; Occhiuzzi, C.; Natale, C.D.; Marrocco, G. Design and experimentation of a batteryless on-skin RFID graphene-oxide sensor for the monitoring and discrimination of breath anomalies. IEEE Sens. J. 2018, 18, 8893-8901. [CrossRef]

89. Le, T.; Thai, T.; Lakafosis, V.; Tentzeris, M.; Lin, Z.; Fang, Y.; Sandhage, K.; Wong, C. Graphene enhanced wireless sensors. In Proceedings of the Sensors 2012 IEEE, Taipei, Taiwan, 28-31 October 2012; IEEE: Piscataway, NJ, USA, 2012.

90. Wu, B.; Zhang, X.; Huang, B.; Zhao, Y.; Cheng, C.; Chen, H. High-performance wireless ammonia gas sensors based on reduced graphene oxide and nano-silver ink hybrid material loaded on a patch antenna. Sensors 2017, 17, 2070. [CrossRef] [PubMed]

91. Ali, M.A.; Cheng, M.M.-C.; Chen, J.C.-M.; Wu, C.-T.M. Microwave gas sensor based on graphene-loaded substrate integrated waveguide cavity resonator. In Proceedings of the 2016 IEEE MTT-S International Microwave Symposium, San Francisco, CA, USA, 22-27 May 2016; IEEE: Piscataway, NJ, USA, 2016.

92. Zhang, L.; Tan, Q.; Kou, H.; Wu, D.; Zhang, W.; Xiong, J. Highly sensitive NH3 wireless sensor based on Ag-RGO composite operated at room-temperature. Sci. Rep. 2019, 9, 9942. [CrossRef] [PubMed] 